\title{
RADIOAU'TOGRAPHIC STUDY OF
}

\section{CELL WALL DEPOSITION \\ IN GROWING PLANT CELLS}

\author{
PETER M. RAY \\ From the Biology Division, Oak Ridge National Laboratory, Oak Ridge, Tennessee and the Division \\ of Natural Sciences, University of California, Santa Cruz, California 95060.
}

\begin{abstract}
Segments cut from growing oat coleoptiles and pea stems were fed glucose- ${ }^{3} \mathrm{H}$ in presence and absence of the growth hormone indoleacetic acid (IAA). By means of electron microscope radioautography it was demonstrated that new cell wall material is deposited both at the wall surface (apposition) and within the preexisting wall structure (internally). Quantitative profiles for the distribution of incorporation with position through the thickness of the wall were obtained for the thick outer wall of epidermal cells. With both oat coleoptile and pea stem epidermal outer walls, it was found that a larger proportion of the newly synthesized wall material appeared to become incorporated within the wall in the presence of IAA. Extraction experiments on coleoptile tissue showed that activity that had been incorporated into the cell wall interior represented noncellulosic constituents, mainly hemicelluloses, whereas cellulose was deposited largely or entirely by apposition. It seems possible that internal incorporation of hemicelluloses plays a role in the cell wall expansion process that is involved in cell growth.
\end{abstract}

\section{NTRODUCTION}

A long-standing problem in plant cell biology is the site at which new material is incorporated into the primary wall during cell enlargement. This is important primarily because it is relevant to the issue whether wall synthesis plays a causative role in the process of cell wall expansion that brings about cell enlargement. In 1858, Nägeli (1) proposed that the primary cell wall grows by intussusception, the intercalation of new material within its structure. The contrary view that during cell enlargement new wall material is deposited only at the wall surface (apposition) was expounded in 1882 by Strasburger (2). Appositional deposition cannot directly cause surface expansion of the cell wall; so, if wall synthesis occurs entirely by apposition, some other mechanism is required to account for the occurrence of wall expansion and cell enlargement.
These alternatives have been argued in numerous, subsequent papers. Electron microscopic observations on the organization of the microfibrillar component of growing walls have been interpreted as generally favoring the hypothesis of apposition (3). Roelofsen (4) recently reviewed the problem and concluded that cellulose is probably added to the growing wall by apposition, whereas noncellulosic wall substances probably can be incorporated internally. However, direct evidence is still meager and conflicting. The classic paper is that of Noll (5) who demonstrated the occurrence of apposition with cell walls of the algae Derbesia and Caulerpa that had been previously impregnated with Prussian blue. By an ingenious study of the self-absorption of radiation by tritium-labeled, growing cell walls of Nitella, Green (6) concluded that new material was being 
added only by apposition. Setterfield and Bayley (7), using light microscope radioautography, concluded that incorporation of both cellulose and noncellulosic material was occurring throughout the thickness of the outer wall of oat coleoptile epidermal cells. Northcote and Pickett-Heaps (8) recently published electron microscope radioautographs of maize root-cap cells; their study indicated incorporation of radioactivity, in some cases, throughout the cell walls and beyond them to the exterior. This radioactivity may have represented principally extracellular mucilage rather than cell wall material. In none of the studies cited did the method afford quantitative information on the distribution of incorporation of new wall material with position through the cell wall.

The present experiments were undertaken to obtain such information for the thick, external walls of growing epidermal cells of oat coleoptiles and pea stems and to ascertain whether growth hormone (auxin) exerts on the pattern of incorporation any effect that might be of significance in relation to the mechanism of cell wall expansion.

\section{METHODS}

\section{Plant Material}

Oat seeds, Avena sativa var. Victory, were germinated on moist filter paper for 3 days at $25^{\circ} \mathrm{C}$. They received $\mathrm{dim}$ red light from a $40 \mathrm{w}$ ruby red safelight for the first day and were kept in darkness thereafter. Under a similar red light, segments 8 $\mathrm{mm}$ long, beginning $3 \mathrm{~mm}$ from the tip, were cut from coleoptiles $2-2.5 \mathrm{~cm}$ tall, and the leaf was removed from each segment.

Pea seeds, Pisum sativum var. Alaska, were germinated for 7 days in vermiculite at $25^{\circ} \mathrm{C}$ in the dark with occasional exposure to $\operatorname{dim}$ red light. Under red light, 8-mm segments were cut from the third internode beginning about $2 \mathrm{~mm}$ below the apical hook.

\section{Radioisotope Incubation}

30 tissue segments were blotted dry and introduced into $1.2 \mathrm{ml}$ of $0.05 \mathrm{~m}$ glucose containing $2.5 \mathrm{mc}$ of glucose $-1{ }^{3} \mathrm{H}$ (Volk Radiochemicals Co., Skokie, IIl. with or without $3 \mathrm{mg} / 1$ indoleacetic acid (IAA); the segments were contained in a Stender dish, $28 \mathrm{~mm}$ inside diameter, the ground rim and cover of which were sealed with silicone grease. Segments that were to be treated with IAA during incubation were pretreated for $10 \mathrm{~min}$ in $3 \mathrm{mg} /$ liter IAA prior to introduction into the labeled medium in order that the growth effect of IA $\Lambda$ would be initiated when the isotope feeding was begun. The incubation dishes were shaken on a reciprocal shaker at about 60 cycles $/ \mathrm{min}$, in the dark at $25^{\circ} \mathrm{C}$. At the time of harvest, 2 or $8 \mathrm{hr}$ after the beginning of incubation, segments were transferred to ice water containing crushed ice, washed several times with ice water, cut in half lengthwise, and transferred to ice-cold fixation fluid.

\section{Fixation and Sectioning}

Tissue specimens were fixed in ice-cold phosphatebuffered osmium tetroxide (9) for $\mathbf{1 6} \mathrm{hr}$, or in icecold phosphate-buffered formaldehyde (10) for 7 $\mathrm{hr}$ followed by ice-cold buffered osmium tetroxide for $11 \mathrm{hr}$. Pea stem segments also were fixed in similarly buffered ice-cold $5 \%$ glutaraldehyde for $16 \mathrm{hr}$ followed by ice-cold buffered osmium tetroxide for $7 \mathrm{hr}$. Segments were washed briefly with ice water and transferred through a graded ethanol/ water series into absolute ethanol and subsequently through propylene oxide into moderately hard Epon (reference 11, 3:7 mixture), which was polymerized by heating for 1 day at $60^{\circ} \mathrm{C}$. Sections (silver) were cut on a Porter-Blum automatic microtome set at $800 \mathrm{~A}$, with a diamond knife, and were picked up onto collodion-coated grids. The sections were cut approximately transverse to the long axis of the tissue segments about $1 \mathrm{~mm}$ from one end of the segment, or, in some cases, in the middle of the segment. They were stained by floating the grids on lead citrate (12) for $7 \mathrm{~min}$, and then were rinsed off rapidly with distilled water.

\section{Radioautography}

In a high-vacuum evaporator, a thin, carbon film was evaporated over the sections. The grids were then attached to glass slides; a monolayer of Ilford L-4 Nuclear Research Emulsion, melted in twice its weight of distilled water, was applied at the gel point by the loop technique (13). They were kept in light-tight containers in the presence of a desiccant, at room temperature, for $2-15 \mathrm{wk}$ depending on the activity in the sections. For development, the grids were removed from the slides under a safelight and floated, emulsion side down, for $1 \mathrm{~min}$ on a drop of freshly prepared developer $(37.8 \mathrm{~g}$ $\mathrm{Na}_{2} \mathrm{SO}_{3}$ and $3.24 \mathrm{~g}$ Eastman Kodak Co. p-phenylenediamine, dissolved in $300 \mathrm{ml}$ distilled water, then filtered) (13) in a black porcelain spot plate at room temperature. Then they were washed briefly in water and floated for $1.5 \mathrm{~min}$ in Kodak F-24 fixer (Eastman Kodak Co., Rochester, N. Y.), and were rinsed rapidly in a stream of distilled water. Care was taken to avoid contact by the developer or fixer with the back sides of the grids, since such had 
been found to be detrimental to the quality of the preparations.

\section{Extraction of Cell Wall Components}

Osmium tetroxide-fixed tissue segments which had been stored in absolute ethanol were washed briefly with water, then treated in the following ways to extract various wall substances differentially, as shown by previous analyses $(14,15)$. To remove galacturonans segments were treated with $5 \mathrm{ml}$ of $0.5 \% \mathrm{Na}$-EDTA, pH 11.5 ; after $20 \mathrm{~min}$, the solution was brought to $\mathrm{pH} 4.5$ with glacial acetic acid, and $0.5 \mathrm{ml}$ of a $2 \%$ solution of pectinase (Nutritional Biochemicals Corporation, Cleveland, O.) was added; $2 \mathrm{hr}$ later the segments were washed with water and returned to absolute ethanol. To remove hemicelluloses segments were kept in $0.05 \mathrm{~N}_{2} \mathrm{SO}_{4}$ for $2 \mathrm{hr}$ in a boiling water bath and then washed with water. To extract all wall components except cellulose segments were extracted successively with pectinase and hot $0.05 \mathrm{~N} \mathrm{H}_{2} \mathrm{SO}_{4}$ as just described, then treated with $4 \mathrm{~N} \mathrm{KOH}$ at room temperature for $6 \mathrm{hr}$, and washed with water. Aliquots of extracts, and of the $\alpha$-cellulose residue after dissolution in $72 \% \mathrm{H}_{2} \mathrm{SO}_{1}$, were counted by scintillation with a Beckman CPM100 at $47 \%$ efficiency. Extracts were then hydrolyzed for $6 \mathrm{hr}$ at $100^{\circ} \mathrm{C}$ with $1 \mathrm{~N} \mathrm{H}_{2} \mathrm{SO}_{4}$, were separated into neutral and acidic fractions with Dowex-l (acetate form), and chromatographed on paper to separate sugar or uronic acid components, as previously described $(14,15)$. Each component was eluted from the paper with water and counted.

The extracted segments were embedded, sectioned, and stained as described above, except that the sections of preparations from which all components but cellulose had been extracted were stained for $20 \mathrm{~min}$ with lead citrate. Even so, the $\alpha$-cellulose preparations had extremely low contrast and their details (except for the silver grains) were invisible on the microscope screen. Photographs brought out a faint, granular deposit which outlined the cell wall structure and which was readily distinguishable from the completely opaque silver grains (example shown in Fig. 16).

\section{Analysis of Data}

Radioautographs were examined and photographed at about $\times 8000$ with a Siemens Elmiskop II or at about $\times 3500$ with an RCA EMU-3, part or all of the outer wall of one epidermal cell being recorded in each picture; enlargements were printed at a final magnification of about 20,000. On the prints the positions of the silver grains over or adjacent to the external wall of epidermal cells (outer epidermis in the case of oat coleoptiles) were determined by recording the distance of the grain from the inner surface of the wall and the entire thickness of the wall at the point at which the grain in question was located. All grains were recorded that occurred in a position between one-quarter of the wall thickness beyond its outer edge and one-half the wall thickness inside the cell from the wall's inner boundary, along all of the outer wall that was visible, except for the triangular, thickened areas between adjacent cells, or along a part of the wall until a total of $\mathbf{5 0}$ grain positions was recorded for the cell. Grains were recorded from at least five different cells from each specimen; more than five cells were analyzed if the frequency of grains was less than 50 per cell, a total of at least 250 grains being recorded for each specimen (300 grains from at least six cells in the case of the pea stem sections). The position and wall thickness measurements for each grain were later divided to give its distance from the inner surface of the wall as a fraction of the wall thickness, and these fractional distances were tabulated into classes of one-twentieth of the wall thickness. The per cent of the total grains found in each position class was then computed for the specimen, and these percentages were averaged for the replicate specimens in each treatment series to find the average grain distribution for the treatment.

\section{RESULTS}

Radioautographs illustrating incorporation of radioactivity into the thick outer wall of the epidermis of oat coleoptiles and pea stems after incubation in glucose- ${ }^{3} \mathrm{H}$ are shown in Figs. 1-8. These clearly demonstrate that incorporation occurs throughout the thickness of the wall right to its outer surface. However, a preference for incorporation at the inner surface of the wall is evident.

The amount of activity associated with the cell wall after an $8 \mathrm{hr}$ incubation was much greater than after a $2 \mathrm{hr}$ incubation. Useful radioautographs of the 8-hr specimens were obtained after exposure of the emulsion for about $3 \mathrm{wk}$ as in Figs. 4 and 12, whereas the radioautographs of the specimens from the $2 \mathrm{hr}$ incubation shown in Figs. 1 and 2 had been exposed for $11 \mathrm{wk}$ and that of the specimen shown in Fig. 3 had been exposed for $15 \mathrm{wk}$. Incorporation is thus clearly progressive with time. As illustrated in Fig. 4, no incorporation occurred in the walls of the occasional, dead epidermal cells that are encountered when a tissue segment is sectioned near one end, even though such dead cells lay adjacent to living cells which had engaged in vigorous incorporation (the dead cells are those that were cut during 


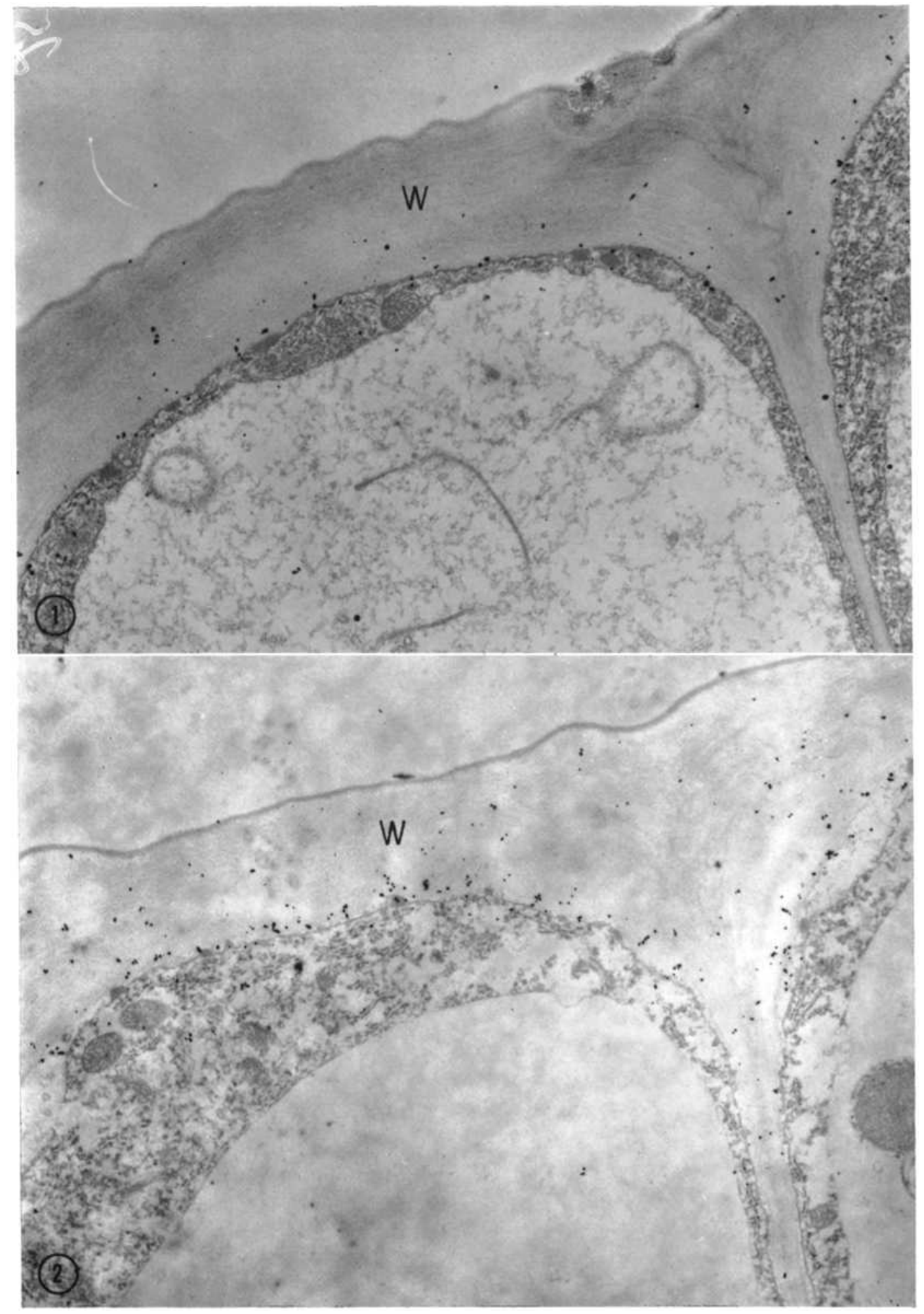

FIgures 1 and 2 Radioautographs of external wall $(W)$ of outer epidermal cells of oat coleoptiles incubated $2 \mathrm{hr}$ in ${ }^{3} \mathrm{H}$-glucose. Formaldehyde- $\mathrm{OsO}_{4}$ fixation. Fig. 1, incubation without IAA; Fig. \&, incubation medium contained $3 \mu \mathrm{g} / \mathrm{ml}$ IAA. Figs. 1 and $2, \times 10,400$. 


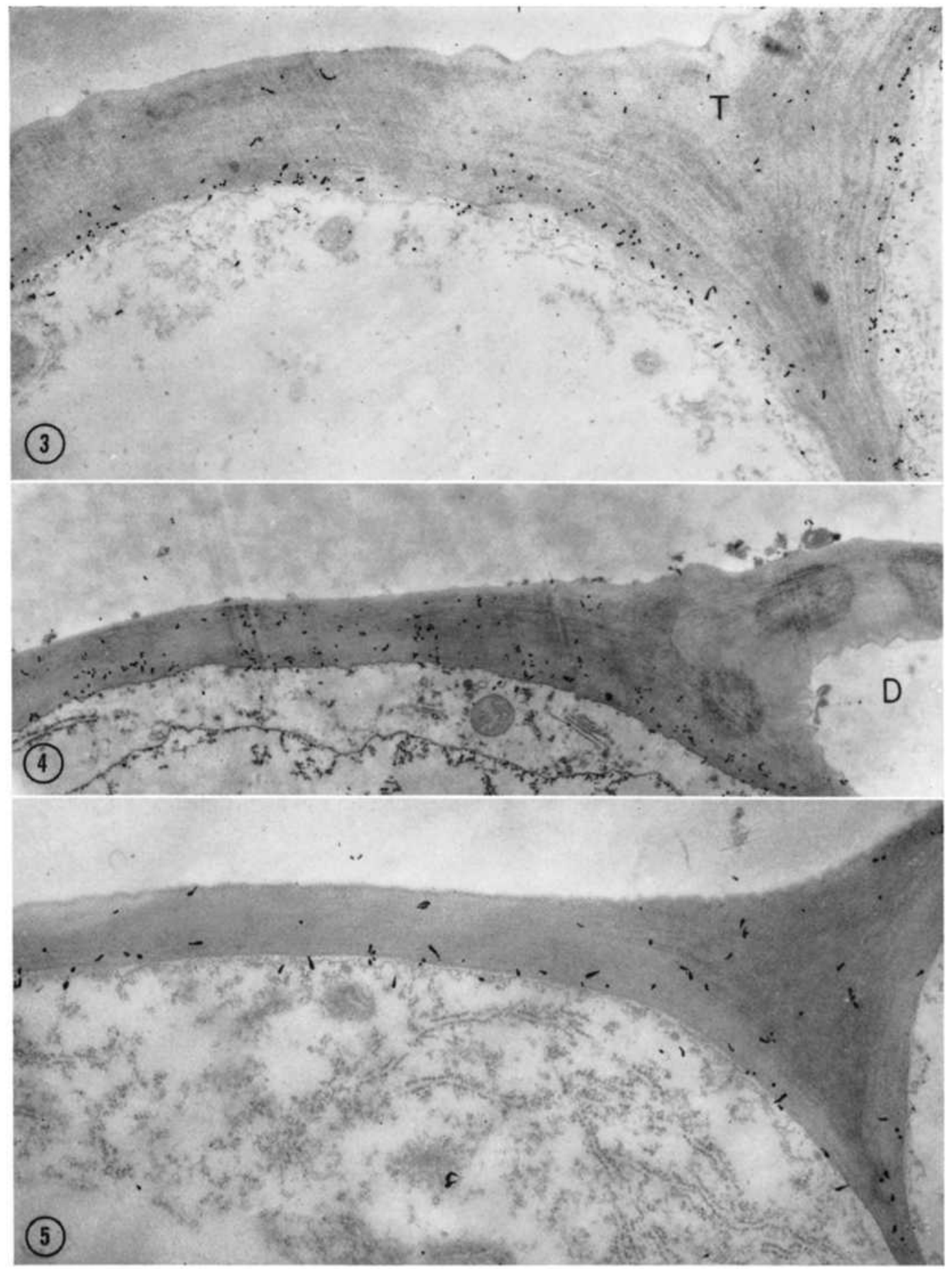

FIGURE 3 Radioautograph of outer epidermal wall from oat coleoptile segment incubated $2 \mathrm{hr}$ in glucose${ }^{3} \mathrm{H}$; emulsion exposed $15 \mathrm{wk}$; shows incorporation into triangular thickened zone between adjacent cells (T). $\times 10,800$.

Figure 4 Radioautograph of outer epidermal wall from oat coleoptile segment incubated $8 \mathrm{hr}$ in glucose${ }^{3} \mathrm{H}$ containing $3 \mu \mathrm{g} / \mathrm{ml}$ IAA. Shows adjacent living and dead $(D)$ cells seen in section cut near free end of tissue segment. $\mathrm{OsO}_{4}$ fixation. $\times 10,400$.

Figure 5 Radioautograph of external wall of inner epidermis from oat coleoptile segment incubated 2 $\mathrm{hr}$ in glucose- ${ }^{3} \mathrm{H}$ plus IAA. Formaldehyde- $\mathrm{OsO}_{4}$ fixation. $\times 14,000$. 
excision of the tissue segment). These observations, and those on radiocomposition described below, indicate that the observed incorporation is not artifactual and is due to cell wall synthesis.

The occurrence of internal incorporation was especially obvious in the heavily thickened corners between adjacent cells of the outer (Figs. 2, 3) and the inner (Fig. 5) epidermis of the oat coleoptile. The central part of these triangular, thickened areas is continuous structurally with the middle lamella that separates adjacent cells within the tissue. Fig. 3 demonstrates a greater incorporation of activity into this central zone than in the cell wall zone intervening between it and the wall surface and indicates the deposition of intercellular substance remote from the protoplast surface, as has been inferred by some authors ( 3 , 4,16 ).

Both internal incorporation and surface deposition evidently occurred in the relatively thin external wall of the coleoptile's inner epidermis (Fig. 5). Because of the extreme thinness of the walls of parenchyma cells it was not possible, in most places in the interior of the tissue, to distinguish whether the observed activity had been incorporated at the surface or in the interior of the wall. However, the distribution of silver grains over occasional thicker areas at cell junctions, as illustrated in Figs. 9-11, indicated that internal incorporation was occurring into parenchyma cell walls and intercellular substance of both coleoptiles and pea stems. However, as in the case of the epidermis, grains appeared to occur most frequently at or near the inner surface of the parenchyma cell walls, i.e., next to the protoplast.

\section{Incorporation Patterns of Cell} Wall Components

Table I shows the distribution of ${ }^{3} \mathrm{H}$ that was found in components of the cell wall when os- mium tetroxide-fixed coleoptile segments were extracted successively with pectinase, hot dilute mineral acid, and $4 \mathrm{~N} \mathrm{KOH}$. The proportion of the total activity found in different fractions and in the sugar and uronic acid components of each fraction was very similar to that previously observed with washed cell walls from unfixed coleoptile segments that had been incubated in glucose $-^{14} \mathrm{C}$ (17). Pectinase removed most of the galacturonic acid, as well as some neutral polysaccharide, from the osmium tetroxide-fixed tissue, in much the same way as from unfixed cell wall material (15). Hot dilute acid removed the bulk of the hemicelluloses, mainly glucuronoarabinoxylan and noncellulosic glucan. As expected after extraction with $4 \mathrm{~N} \mathrm{KOH}$, the residue $(\alpha$-cellulose) yielded principally glucose upon hydrolysis.

Figs. 12-16 show examples of radioautographs of the outer epidermal wall of a control specimen and of specimens that had been extracted with these solvents separately or in combination. Fig. 17 shows the mean distribution of silver grains with position over the outer epidermal wall in each of these treatments.

Most of the radioactivity that had been incorporated into the interior of the cell wall was removed by extraction with hot dilute acid, but not by pectinase. This shows that internal incorporation is due to introduction of hemicelluloses. Internal incorporation of galacturonan seems probable but cannot be proved from these data, since galacturonic acid comprises such a small proportion of the cell wall. That a substantial proportion of the incorporated activity could be protein is ruled out by the low protein content of cell wall material (26), by the fact that bulk protoplasmic protein becomes labeled only weakly in this type of isotope experiment (reference 16, and radioautographic evidence discussed below), and

Figs. 6-8 are radioautographs of external wall of epidermis from pea stem segments incubated $2 \mathrm{hr}$ in glucose- ${ }^{3} \mathrm{H}$.

FIGUre 6 Incubation without IAA. Glutaraldehyde-OsO fixation. $\times \mathbf{9 , 4 0 0}$.

Figuke 7 Incubation medium contai ned $3 \mu \mathrm{g} / \mathrm{ml}$ IAA. Glutaraldehyde- $\mathrm{O}_{3} \mathrm{O}_{4}$ fixation $\times 9,400$.

FIGURe 8 Incubation medium contained IAA. Shows incorporation into triangular thickened area between adjacent epidermal cells. $\mathrm{OsO}_{4}$ fixation. $\times 10,400$. 

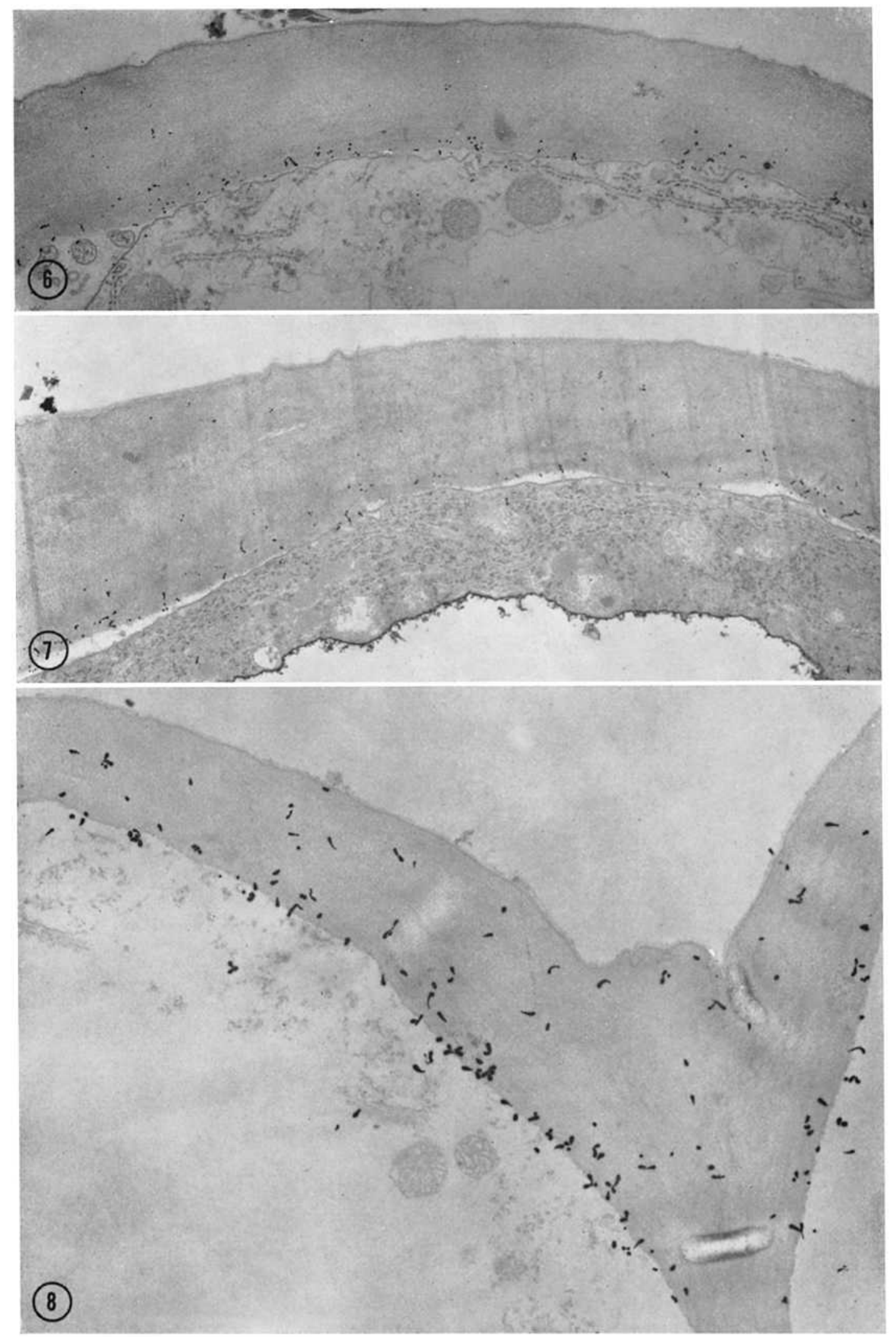
by the data given in Table I which show that most of the radioactivity in the hydrolysates can be accounted for as sugars and uronic acids.

In radioautographs of the $\alpha$-cellulose residue, most of the silver grains were found near the inner surface of the wall. This shows that the cellulose component of this growing wall is deposited largely or entirely by apposition.

The incorporation pattern for noncellulosic substances, principally hemicelluloses, was obtained (Fig. 17 e) by subtracting from the whole wall profile (Fig. $17 d$ ) the $\alpha$-cellulose profile (Fig. $17 b$ ) multiplied by 0.29 , the fraction of total incorporation found in $\alpha$-cellulose. (This assumes that the per cent of total activity incorporated into $\alpha$-cellulose is the same in the outer epidermal wall as in the tissue as a whole.) Fig. $17 e$ indicates that hemicelluloses are being incorporated relatively evenly through the cell wall, although deposition of a surface layer accompanying the cellulose is also definitely suggested.

\section{Effect of Growth Hormone}

This was investigated by analyzing, as explained in Methods, the distribution of grains over the external wall of the epidermis of a series of oat coleoptile and pea stem segments incubated for 2 $\mathrm{hr}$ in glucose $-{ }^{3} \mathrm{H}$ with or without IAA.

The mean grain ciistributions obtained for 10 coleoptile segments with and without IAA are shown in Fig. 18, and statistical data for this experiment are given in Table II. The data indicate a significantly different pattern of incorporation in the two treatments, relatively more incorporation into the interior of the cell wall occurring in the presence of IAA.

Analysis of the racioautographs showed considerable variation in grain density both from cell to cell in a given specimen and, more strik- ingly, from specimen to specimen. The latter variation was correlated with the position of secioning; sections cut from near the center of a tissue segment had much less radioactivity than those cut from near the end of a tissue segment, as would be expected from earlier observations $(19,21)$. However, the distribution of grains with position through the thickness of the cell wall was similar for the two kinds of sections, within a given incubation treatment; therefore the data from both kinds of sections have been pooled to obtain the mean distributions in Fig. 18 and Table II. Each average is based on seven specimens sectioned near the end and three other specimens sectioned near the center.

The results of a similar auxin experiment with pea stem segments are shown in Fig. 19. Fewer specimens were sectioned and analyzed in this case, but the results agree at least qualitatively with those from oat coleoptiles, more internal incorporation being indicated in the epidermal walls of auxin-treated tissue.

\section{DISCUSSION}

These observations confirm the report of Setterfield and Bayley (7) that internal incorporation into oat coleoptile epidermal walls occurs. Under the incubation conditions employed in the present experiments, the incorporation of radioactivity into the cell wall reflects closely its normal chemi cal composition, so that the radioactivity detected in the cell wall must be due to synthesis of its major components. Contrary to Setterfield and Bayley's (7) conclusion, the present data s'ow that a substantial fraction of the newly made wall material, including all or virtually all of the new cellulose, is deposited appositionally at the wall surface. The radioautographs also indicate the occurrence of both apposition and internal incorporation in the cell walls of parenchyma tissue.

FIGURE 9 Radioautograph of cell walls and intercellular material at junction of three parenchyma cells from oat coleoptile segment incubated $2 \mathrm{hr}$ in glucose- ${ }^{3} \mathrm{H}$ plus IAA. Formaldehyde-O $\mathrm{sO}_{4}$ fixation. $\times 10,800$.

FIGURE 10 Radioautograph of cell walls and intercellular material at junction of three cortical parenchyma cells from pea stem segment incubated $2 \mathrm{hr}$ in glucose- ${ }^{3} \mathrm{H}$ plus IAA. Formaldehyde- $\mathrm{OsO}_{4}$ fixation. $\times 7000$.

FIGURE 11 Radioautograph of parenchyma cells from phloem of pea stem segment incul bated $2 \mathrm{hr}$ in glucose- ${ }^{3} \mathrm{H}$; shows incorporation into cell walls and into intercellular materia(arrow). Glutaraldehyde $\mathrm{OsO}_{4}$ fixation. $\times 7000$. 

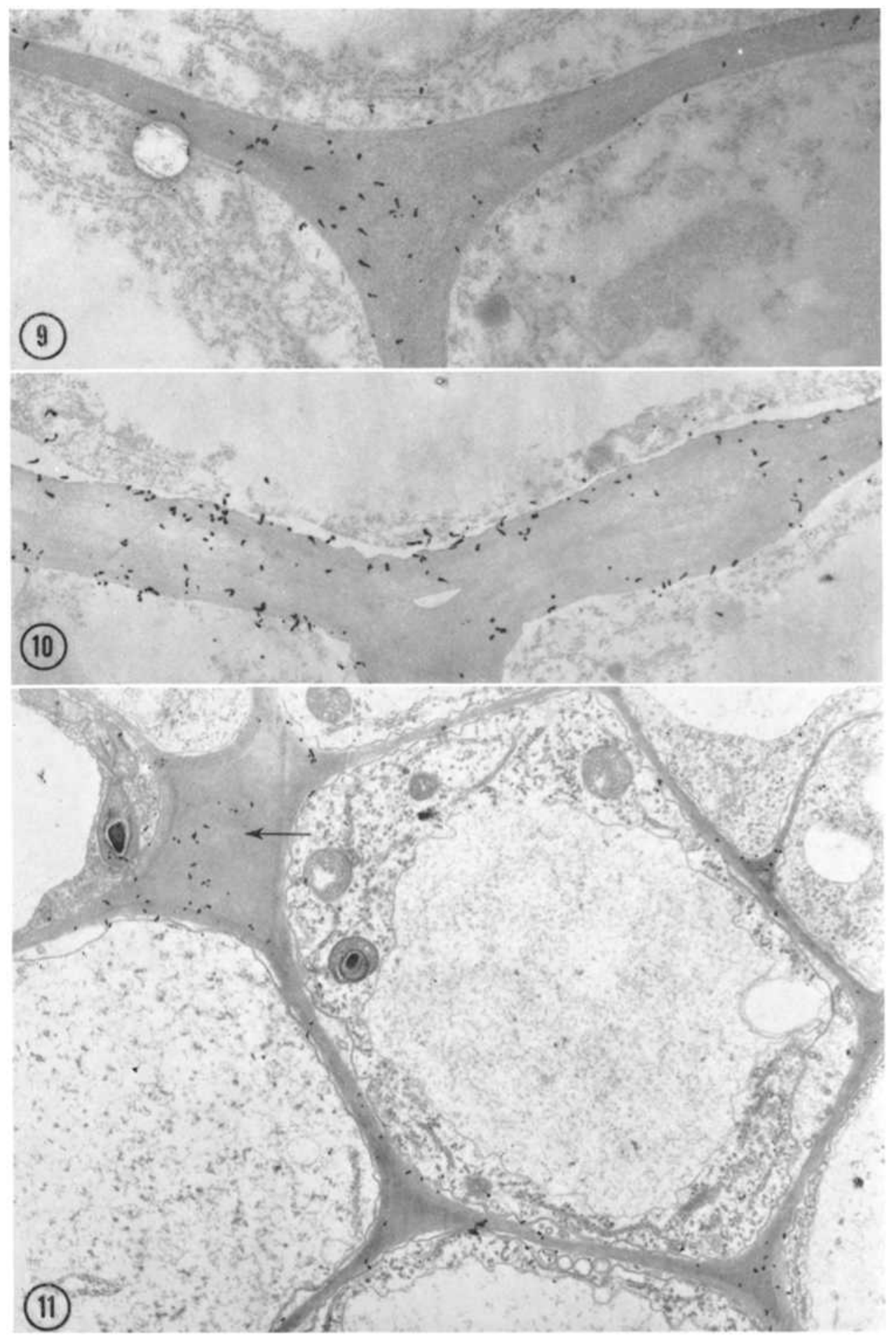

Peter M. Ray Cell Wall Deposition in Growing Plant Cells 
TA B LE I

Distribution of Activily among Cell Wall Components of ${ }^{3} \mathrm{H}$-labeled Oat Coleoptiles

Coleoptile segments had been incubated $8 \mathrm{hr}$ in glucose- ${ }^{3} \mathrm{H}$ plus IAA and fixed with $\mathrm{OsO}_{4}$. Details of extraction and hydrolysis are given in Methods.

\begin{tabular}{|c|c|c|c|c|c|c|c|c|c|c|}
\hline \multirow[t]{2}{*}{ Extract } & \multirow{2}{*}{$\begin{array}{c}\text { Activity in } \\
\text { extract as } \\
\text { per cent } \\
\text { of total }\end{array}$} & \multicolumn{9}{|c|}{ Activity in components of hydrolysate, as per cent of total recovered* } \\
\hline & & Gle & Gal & Man & Ara & $\mathrm{x}_{\mathrm{yl}}$ & GX & MGX & Gal U & other UA \\
\hline Pectinase & 8.7 & 2.9 & 3.3 & 1.1 & 2.0 & 2.9 & 6.3 & 4.2 & 43.0 & 7.6 \\
\hline $0.05 \mathrm{~N} \mathrm{H}_{2} \mathrm{SO}_{4}$ & 58.8 & 14.7 & 2.8 & 0.6 & 20.1 & 20.4 & 13.3 & 3.8 & 1.9 & 7.3 \\
\hline $4 \mathrm{~N} \mathrm{KOH}$ & 3.4 & 26.9 & 18.9 & 3.3 & 16.1 & 24.1 & 1.0 & 0.9 & 2.0 & 1.1 \\
\hline $72 \% \mathrm{H}_{2} \mathrm{SO}_{4}$ & 29.1 & 92.6 & 0 & 0.3 & 0 & 2.8 & 0 & 0 & 0 & 0 \\
\hline
\end{tabular}

*Following abbreviations are used: GX, glucuronosylxylose; MGX, 4-O-methylglucuronosylxylose; other UA, other aldobiouronic acids and galacturonic acid oligomers; Glc; glucose; Gal, galactose; Man, mannose; Ara, arabinose; Xyl, xylose; Gal U, galacturonic acid. Activity of components is given as per cent of the total activity that was recovered from chromatograms of each hydrolysate, including unidentified activity at the origin and elsewhere.

Although silver grains occurred over the cytoplasm, they were much less abundant there than over the cell wall and were not evidently associated with any particular cytoplasmic organelles. Because the experiments involved a relatively long incubation period in substrate of low specific activity, it was to be expected that the amount of radioactivity that might be found at cytoplasmic sites of wall polysaccharide synthesis or transport would be negligible compared to that which had been incorporated into the cell wall (see reference 8). Actually silver grains occurred on the cell cavity side of labeled epidermal walls just as noticeably when cytoplasm was absent owing to shrinkage or poor fixation (Fig. 8), as when wellpreserved cytoplasm was present there. This finding and the following considerations of radioautographic resolution indicate that the silver grains found on the cell lumen near the epidermal wall are almost entirely due to radioactivity located at the wall surface.

Previous data $(18,19)$ show that under the conditions used in the present experiments the amount of cell wall material in coleoptile segments can increase by not more than $5 \%$ in $2 \mathrm{hr}$. Thus an appositionally deposited layer of new wall material can comprise not more than $5 \%$ of the wall thickness after $2 \mathrm{hr}$. That this statement holds specifically for the coleoptile epidermal wall is indicated by the radioautographs after an $8 \mathrm{hr}$ incubation, in which the apposed wall layer comprises not more than about $15 \%$ of the wall thickness (Fig. 17). Therefore, in the radioautographs from the $2 \mathrm{hr}$ incubations, the apposed wall layer can be regarded as a thin, linear source of radiation located in the position class between 0 and $5 \%$ of the wall thickness.

From theoretical information given by Caro (reference 20, Fig. 4) for the present type of radioautography, I computed, by a numerical integration method, the grain distribution to be expected on either side of a thin line source. This result is plotted as the dotted line in Fig 18, the horizontal (distance) scale being chosen so as to conform with the experimentally found mean epidermal wall thickness of $1.5 \mu$. Clearly the grain distribution actually observed on the cytoplasmic side of the wall surface corresponds well with what is to be expected for ${ }^{3} \mathrm{H}$ radiation emanating from the wall surface. The grain profile immediately inside the wall from its inner surface seems to reflect this expected distribution also.

In view of this correspondence, we can regard the grain distribution observed on the cytoplasmic side of the wall surface as providing an internal measure of radioautographic resolution, by means of which we can at least approximately correct the grain profile found in the interior of the cell wall for the occurrence of grains that are due to the concentration of radioactivity at the inner surface. For a labeled surface layer restricted to the $0-0.05$ position class, this correction takes the form $f^{\prime}{ }_{x}=f_{x}-f_{-x}$ where $f^{\prime}{ }_{x}$ is the frequency of grains (in the position class whose lower boundary is $x$ ) that are not due to radiation from the surface 

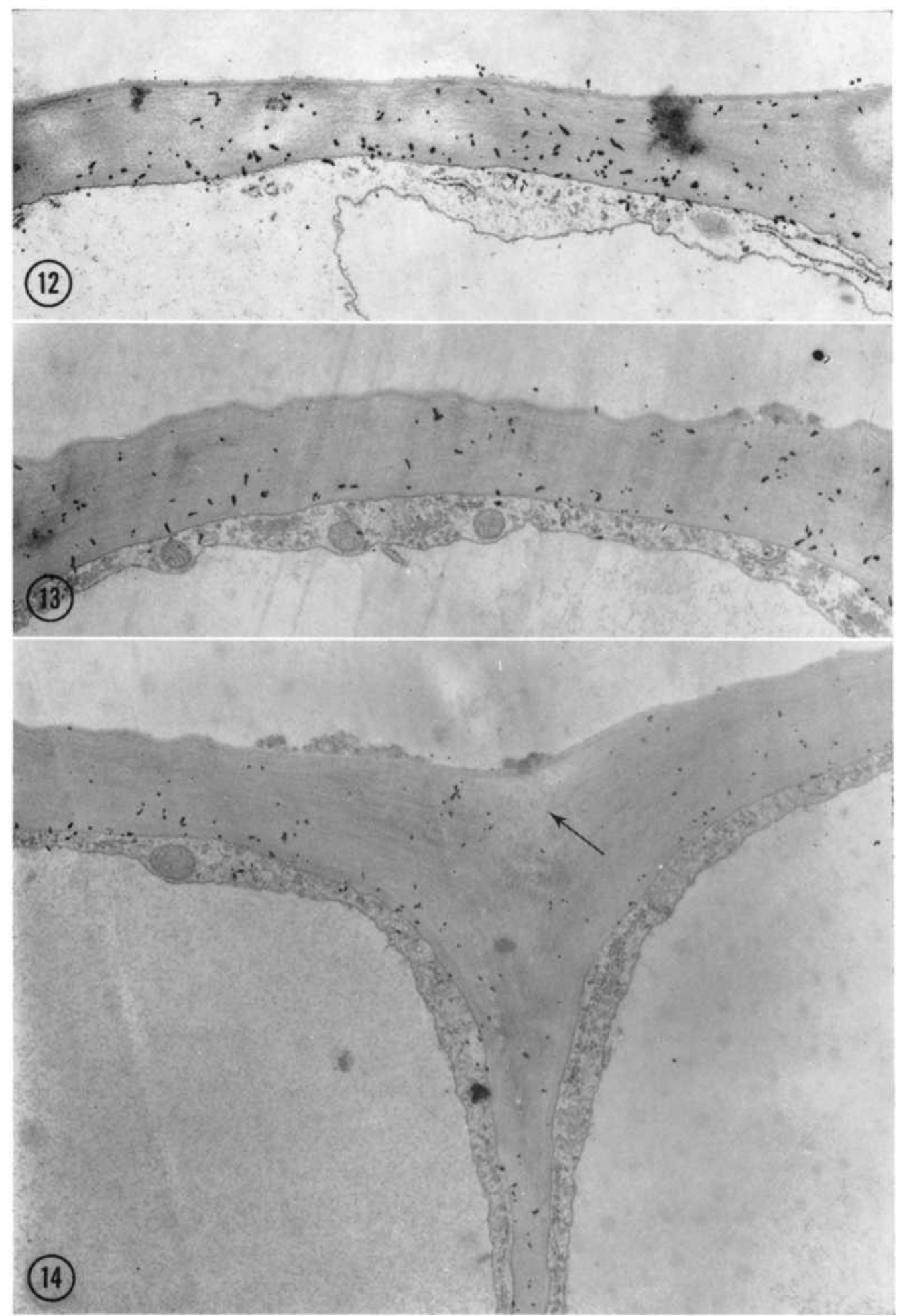

Figs. 12-16 Radioautographs of outer epidermal walls from oat coleoptiles incubated $8 \mathrm{hr}$ in glucose- ${ }^{3} \mathrm{H}$ plus IAA, fixed with $\mathrm{OsO}_{4}$, then extracted with solvents to remove cell wall components differentially. Radioautographic exposure 3.5 wk, except for Fig. 16 which shows 9.5 wk exposure.

Figure 12 Unextracted control. $\times 9,900$.

Figures 13 and 14 Extracted with pectinase. Note indication of removal of material from triangular thickened zone between cells in Fig. 14 (arrow). $\times 9,900$. 


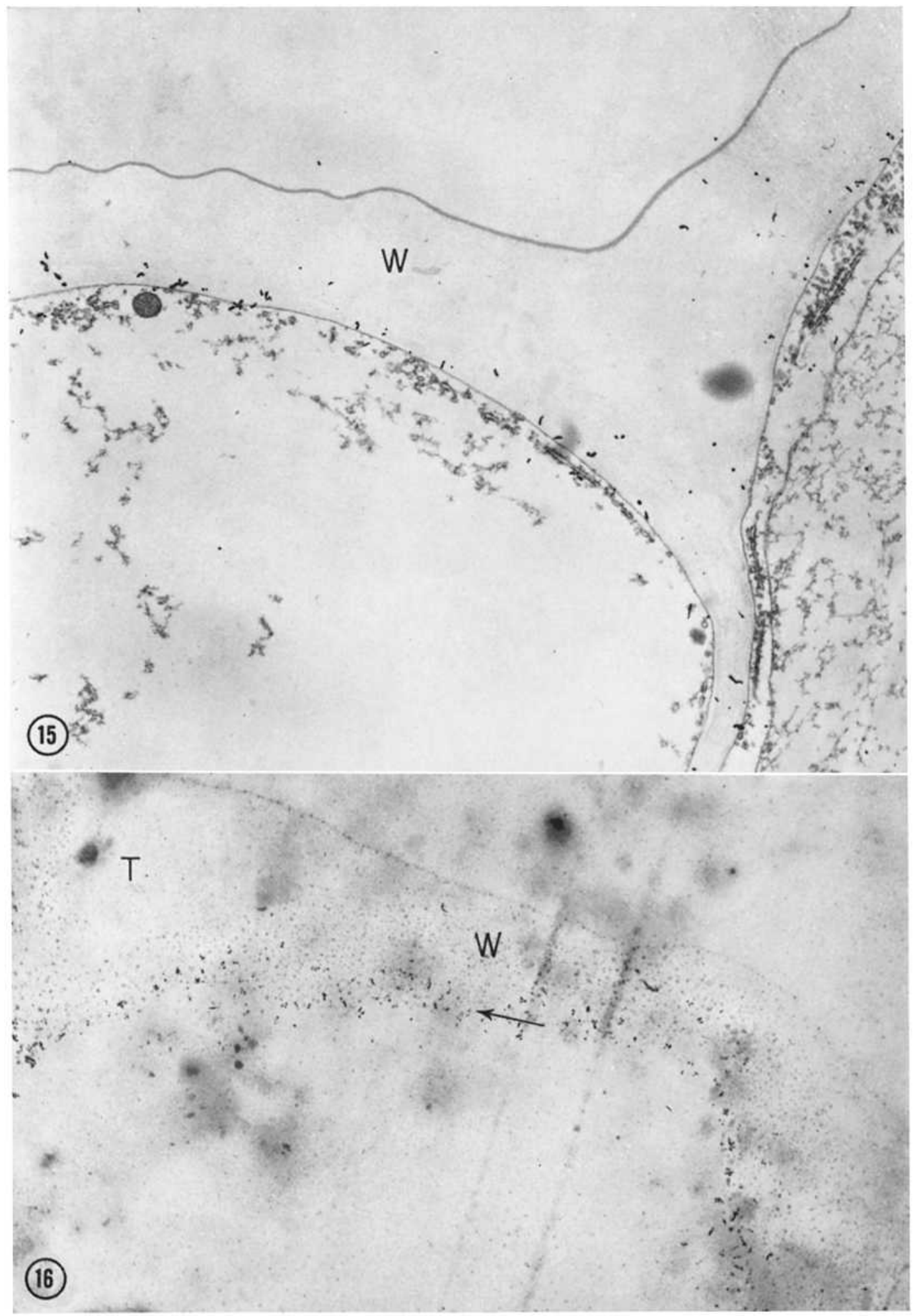

Figure 15 Extracted with hot $0.05 \mathrm{~N}_{2} \mathrm{SO}_{4}$ to remove hemicelluloses. $\times 9,900$.

Figune 16 Extracted successively with pectinase, hot $0.05 \mathrm{~N} \mathrm{H}_{2} \mathrm{SO}_{4}$, and $4 \mathrm{~N} \mathrm{KOH}$, to remove all wall components except cellulose. A faint granular deposit outlining the cellulose residue $(\boldsymbol{W})$ and made visible by photographic enhancement of contrast (see Methods) is to be distinguished from the silver grains (arrow) which are located mostly near the inner surface of the cell wall. $T$, triangular thickened zone between adjacent epidermal cells. $\times \mathbf{9 , 9 0 0}$. 


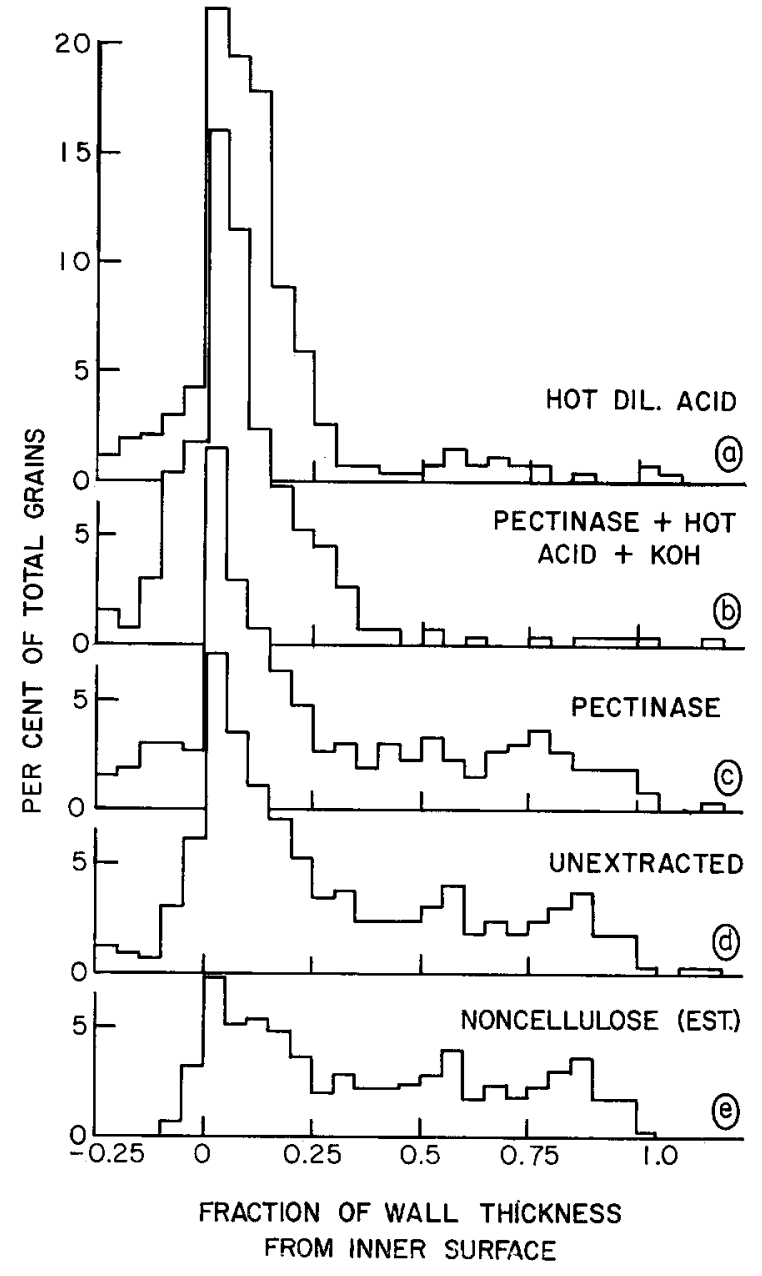

Figure 17 Distribution of silver grains over and adjacent to outer epidermal walls of coleoptile segments incubated $8 \mathrm{hr}$ in glucose $-{ }^{3} \mathrm{H}$ plus IAA, fixed with $\mathrm{OsO}_{4}$ and extracted with $(a)$ hot $0.05 \mathrm{~N}$ $\mathrm{H}_{2} \mathrm{SO}_{4}$ only; $(b)$ pectinase, hot $0.05 \times \mathrm{H}_{2} \mathrm{SO}_{4}$, and $4 \mathrm{~N} \mathrm{KOH}$; (c) pectinase only; $(d)$ unextracted control; $(e)$ shows estimated distribution of incorporation into noncellulosic substances, derived as explained in the text. Each distribution is based on measurement of a total of approximately 600 grains from six different cells. layer, and $f_{x}$ and $f_{-x}$ are the observed grain frequencies in position class $x$ and in the position class $-x$ symmetrically opposite $x$ on the other (cytoplasmic) side of the surface layer. In principle a correction should also be made for radiation arising from each position class within the wall but, since the density of radioactivity is relatively low and relatively uniform throughout the wall, except at its inner surface, such a correction would be of minor importance compared to that for radiation from the surface and will not be made here.

According to this interpretation, the proportion $f^{\prime}{ }_{o}$ of the total radioactivity that is located in the surface layer is given by $f^{\prime}{ }_{o}=f_{o}+2 \sum^{-x} f_{x}$ where the last term is the sum of grain frequencies over all negative values of $x$, i.e. on the cytoplasmic side of the cell wall.
In Table III $f^{\prime}{ }_{o}$ and $f^{\prime}{ }_{x}$ values, which represent the estimated actual distribution of radioactivity with position through the cell wall, are summarized for the minus and plus IAA treatments from the experiments of Figs. 18 and 19. The results indicate that the oat coleoptile epidermal cells in the absence of auxin deposited $71 \%$ and in the presence of auxin $52 \%$ of the newly synthesized cell wall material at the wall surface. For pea stem epidermis the comparable values were 85 and $65 \%$.

The actual magnitude of the auxin effect on internal incorporation depends upon whether the hormone altered the incorporation pattern without affecting total synthesis or, instead, increased internal incorporation without affecting apposition. In the former case the internal incorporation values in Table III should be a correct measure 

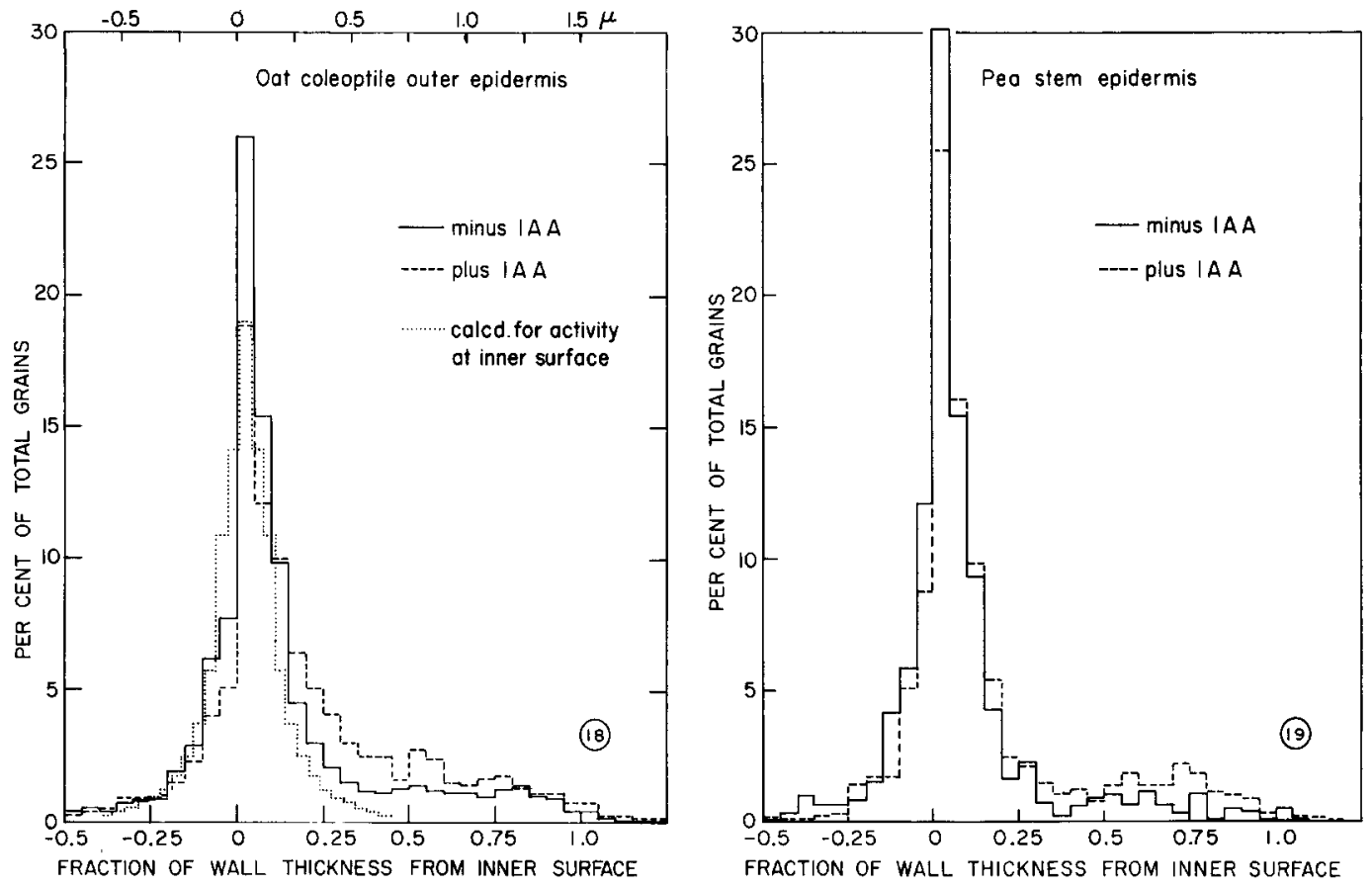

Figs. 18 and 19, distribution of silver grains over and adjacent to outer epidermal wall of oat coleoptile and pea stem segments incubated $2 \mathrm{hr}$ in glucose- ${ }^{3} \mathrm{H}$ without IAA (solid line) and with IAA (dashed line).

Figure 18 Oat coleoptile epidermis. Each distribution is based on the measurement of a total of approximately 2700 grains, from radioautographs of at least five cells from each of 10 coleoptile segments. Dotted line (abscissa at top) shows expected grain distribution calculated for a linear source of ${ }^{3} \mathrm{H}$ radiation confined to the $0-0.05$ position class, as explained in text.

Frgure 19 Pea stem epidermis. Fach distribution is based on measurement of a total of approxinately 900 grains, from radioautographs of six cells from each of three pea stem segments.

of the auxin effect, whereas in the latter case the effect should be measured by expressing internal incorporation as a fraction of the incorporation at the wall surface, which would be a larger effect than that indicated by the values in Table II. It was not possible to distinguish between these alternatives, not only because of the uncertainties in determining absolute radioactivity by radioautography, but also because of the previously mentioned large variation in grain frequency (thus of incorporation) from cell to cell and specimen to specimen (see Results). The true magnitude of the auxin effect on internal incorporation is likely to lie somewhere between the two mentioned alternatives as extremes.

The evidence that internal incorporation is due to noncellulosic wall components, particularly hemicelluloses, indicates that the auxin effect on internal incorporation is exerted on the incorpora- tion of hemicelluloses. The existence of such an effect, similar in magnitude to the effect of auxin on growth rate, would suggest that internal incorporation of hemicelluloses may serve to induce stress relaxation and hence expansion of the cell wall. But the contingency must also be entertained that cell wall expansion, induced in some other way by auxin, facilitates internal incorporation and leads to the observed effect. However, the proportion of new material that is being incorporated internally in the presence of auxin is large enough that it is hard to imagine that it would not contribute in some degree to the expansion growth of the cell wall.

The principles of radioautographic resolution applied above affect with equal importance the interpretation of data in Fig. 17. A quantitative correction of grain distribution for grains due to the highly radioactive apposed wall layer cannot 
T AB LE I I

Grain Distribution Data for Epidermal Wall of Oat Coleoptile Segments Incubated $2 \mathrm{hr}$ in glucose ${ }^{3} \mathrm{H}$ with or without IAA

Each figure is the mean \pm standard error of the mean for 10 coleoptile segments, the mean lengths of which, at end of incubation, were $8.45 \mathrm{~mm}$ without IAA and $9.30 \mathrm{~mm}$ with IAA (initial length $8.0 \mathrm{~mm}$ ).

\begin{tabular}{|c|c|c|c|}
\hline \multirow{2}{*}{\multicolumn{2}{|c|}{$\begin{array}{l}\text { Fraction of wall thick- } \\
\text { ness from inner surface* }\end{array}$}} & \multicolumn{2}{|c|}{ Total grains } \\
\hline & & Without IAA & With IAA \\
\hline & & $\%$ & $\%$ \\
\hline-0.30 & --0.15 & $3.7 \pm 0.6$ & $3.4 \pm 0.3$ \\
\hline-0.15 & $-\quad 0.0$ & $16.7 \pm 1.3$ & $11.4 \pm 0.7$ \\
\hline 0.0 & $-\quad 0.15$ & $51.1 \pm 1.8$ & $41.0 \pm 2.5$ \\
\hline 0.15 & $-\quad 0.30$ & $9.6 \pm 2.1$ & $15.6 \pm 1.1$ \\
\hline 0.30 & $-\quad 0.45$ & $3.7 \pm 0.4$ & $8.0 \pm 0.9$ \\
\hline 0.45 & $-\quad 0.60$ & $3.9 \pm 0.4$ & $6.7 \pm 0.5$ \\
\hline 0.60 & 0.75 & $3.3 \pm 0.4$ & $4.5 \pm 1.0$ \\
\hline 0.75 & - $\quad 0.90$ & $3.7 \pm 0.4$ & $4.2 \pm 0.5$ \\
\hline 0.90 & $-\quad 1.05$ & $1.6 \pm 0.2$ & $2.6 \pm 0.4$ \\
\hline
\end{tabular}

* Negative values are on cytoplasmic side of wall surface.

be made here because the apposed layer is thick enough that it cannot be regarded as a thin linear source. But the descending distribution of grains extending to about one-quarter of the wall thickness in Fig. $17 a$ and $b$, which is mirrored by a similar distribution outside the cell wall next to the apposed layer, must be due largely, if not entirely, to radiation coming from the apposed layer and does not indicate internal incorporation of cellulose. This strengthens the conclusion given above that deposition of cellulose in this cell wall is essentially entirely by apposition.

The more limited resolution of the radioautographic technique employed by Setterfield and Bayley (7) and the more lengthy isotope incubation period in their cellulose experiment (thus a much thicker apposed layer) seem to explain why those authors did not detect clearly the apposition

\section{BIBLIOGRA PHY}

1. NÄGeli, C. 1858. Dịe Stärkekörner: Morphologisch, physiologisch, chemisch-physicalische und systematisch-botanische. Monographie. Schulthess \& Co., Zürich.

2. Strasburger, E. 1882. Ueber den Bau und das Wachsthum der Zellhäute. G. Fischer, Jena.

3. Roelofsen, P. A. 1959. The plant cell-wall. In
T AB LE II I

Estimated Distribution of Radioactivity Incorporated into Epidermal Cell Walls

From data of Figs. 18 and 19. Internal correction has been applied for distribution of grains due to radioactivity at inner surface, as explained in the text.

\begin{tabular}{|c|c|c|c|c|}
\hline \multirow[b]{3}{*}{$\begin{array}{c}\text { Fraction of wall } \\
\text { thickness }\end{array}$} & \multicolumn{4}{|c|}{ Total activity } \\
\hline & \multicolumn{2}{|c|}{$\begin{array}{c}\text { Oat colcoptile } \\
\text { outer epidermis }\end{array}$} & \multicolumn{2}{|c|}{$\begin{array}{l}\text { Pea stem } \\
\text { epidermis }\end{array}$} \\
\hline & $\begin{array}{l}\text { Without } \\
\text { IAA }\end{array}$ & $\begin{array}{l}\text { With } \\
\text { IAA }\end{array}$ & $\begin{array}{l}\text { Without } \\
\text { IAA }\end{array}$ & $\begin{array}{l}\text { With } \\
\text { IAA }\end{array}$ \\
\hline & $\%$ & $\%$ & $\%$ & $\%$ \\
\hline-0.05 & 70.8 & 52.4 & 85.0 & 64.9 \\
\hline $0.05-0.25$ & 14.0 & 20.7 & 7.0 & 16.5 \\
\hline $0.25-0.55$ & 4.8 & 12.4 & 2.3 & 5.8 \\
\hline $0.55-1.0^{*}$ & 10.4 & 14.5 & 5.7 & 12.8 \\
\hline
\end{tabular}

* Correction does not apply to data for this region.

of cellulose and concluded that cellulose was being deposited throughout the cell wall.

In conclusion, it is of interest to note the comparison between the problem of cell wall formation in plants and the problem of collagen and chondroitin sulfate formation in animal tissues, concerning which a dispute has also existed about the occurrence of deposition at, as opposed to remote from, the cell surface. Recent electron microscope radioautography has demonstrated that both kinds of deposition of collagen take place (22-25).

I thank Dr. Lucien Caro for making available facilities and for his interest in and advice on the project and Miss Maria Schnos for valuable assistance with the experiments.

This work was sponsored by the Atomic Energy Commission under contract with Union Carbide Corporation and was supported in part by a grant from the National Science Foundation.

Received for publication 8 March 1967; revision accepted 7 August 1967.

Encyclopedia of Plant Anatomy. Gebrüder Borntraeger, Berlin. 3 (4).

4. Roelofsen, P. A. 1965. Ultrastructure of the wall in growing cells and its relation to the direction of growth. In Advances in Botanical Research. R. D. Preston, editor. Academic Press Inc., New York. 
5. NoLl, F. 1887. Experimentelle Untersuchungen über das Wachstum der Zellmembran. Abhandl. Senckenberg. Naturforsch. Ges. 15:101.

6. Green, P. B. 1958. Concerning the site of addition of new wall substances to the elongating Nitella cell wall. Am. J. Botany. 45:111.

7. Setter field, G., and S. T. Bayley. 1959 Deposition of cell walls in oat coleoptiles. Can. J. Botany. 37:861.

8. Northcote, D. H., and J. D. Pickett-Heaps. 1966. A function of the Golgi apparatus in polysaccharide synthesis and transport in the root-cap cells of wheat. Biochem. J. 98:159.

9. Millonig, G. 1962. Further observations on a phosphate buffer for osmium solutions in fixation. In Electron Microscopy: Fifth International Congress on Electron Microscopy Held in Philadelphia, Pennsylvania, August 29th to September 5th 1962. S. S. Breese, Jr., editor. Academic Press Inc., New York. 2: P 8.

10. Pease, D. C. 1964. Histological Techniques for Electron Microscopy. Academic Press Inc., New York. 2nd edition.

11. Lufr, J. H. 1961. Improvements in epoxy embedding methods. J. Biophys. Biochem. Cytol. 9:409.

12. Reynolns, E. S. 1963 . The use of lead citrate at high $\mathrm{pH}$ as an electron-opaque stain in electron microscopy. J. Cell Biol. 17:208.

13. Garo, L. G., and R. P. van Tubergen. 1962. High-resolution autoradiography. I. Methods. J. Cell Biol. 15:173.

14. Ray, P. M. 1963. Sugar composition of oat coleoptile cell-walls. Biochem. J. 89:144.

15. RAY, P. M., and D. A. RotTenberg. 1964. Uronic acid constituents of oat-coleoptile cell walls. Biochem. J. 90:646.

16. Albersheim, P. 1965. The substructure and function of the cell wall. In Plant Biochemistry.
J. Bonner and J. E. Varner, editors. Academic Press Inc., New York.

17. Ray, P. M., and D. B. Baker. 1965. The effect of auxin on synthesis of oat coleoptile cell wall constituents. Plant Physiol. 40:353.

18. RAy, P. M. 1962. Cell wall synthesis and cell elongation in oat coleoptile tissue. Am. $J$. Botany. 49:928.

19. BakeR, D. B., and P. M. RAY. 1965. Direct and indirect effects of auxin on cell wall synthesis in oat coleoptile tissue. Plant Physiol. 40:345.

20. Caro, L. G. 1962. High-resolution autoradiography. II. The problem of resolution. J. Cell Biol. 15:189.

21. Ochs, G., and R. Pohl. 1959. Der Einfluss von Fermentgiften, Cumarin und Chelatbildnern auf die Zuckeraufnahme und Zellulosesynthese der Avena-Coleoptile. Phyton Buenos Aires. 13:77.

22. Fewer, D., J. Threadgold, and H. Sheldon. 1964. Studies on cartilage. V. Electron microscopic observations on the autoradiographic localization of $\mathrm{S}^{35}$ in cells and matrix. J. Ultrastruct. Res. 11:166.

23. Revel, J.-P., and E. D. Hay. 1963. An autoradiographic and electron microscopic study of collagen synthesis in differentiating cartilage. Z. Zellforsch. Mikroskop. Anat. Abt. Histochem 61:110.

24. Ross, R., and E. P. Benditt. 1965. Wound healing and collagen formation. V. Quantitative electron microscope radioautographic observations of proline- $\mathrm{H}^{3}$ utilization by fibroblasts. J. Cell Biol. 27:83.

25. Porter, K. R. 1964. Cell fine structure and biosynthesis of intercellular macromolecules. Biophys. J. 4 (Suppl.):167.

26. LAMPORT, D. T. A. 1965. The protein component of primary cell walls. In Advances in Botanical Research. R. D. Preston, editor, Academic Press Inc., New York. 2. 